\title{
Common variable immunodeficiency and isosporiasis: first report case
}

\author{
Gisele Barbosa e Silva ${ }^{[1]}$, Karla Pereira Fernandes ${ }^{[1]}$ and Gesmar Rodrigues Silva Segundo ${ }^{[1],[2]}$
}

[1]. Ambulatório de Alergia e Imunologia, Hospital de Clínicas, Universidade Federal de Uberlândia, Uberlândia, MG. [2]. Faculdade de Medicina, Universidade Federal de Uberlândia, Uberlândia, MG.

\section{ABSTRACT}

We report a severe case of diarrhea in a 62-year-old female HIV-negative patient from whom Giardia lamblia and Isospora belli were isolated. Because unusual and opportunistic infections should be considered as criteria for further analysis of immunological status, laboratory investigations led to a diagnosis of common variable immunodeficiency (CVID). This is the first reported case of isosporiasis in a patient with CVID and illustrates the importance of being aware of a possible link, particularly in relation to primary immunodeficiency.

Keywords: Isosporiasis. Primary immunodeficiency. Common variable immunodeficiency.

\section{INTRODUCTION}

Isosporiasis is a parasitic disease caused by the protozoa Isospora belli and Isospora natalensis (Family, Eimeriidae; Order, Eucoccidiida; Suborder, Eimeriorina; Class, Sporozoa; Subclass, Coccidia; Phylum, Apicomplexa), the various species of which infect humans, nonhuman primates and other vertebrates (cats, dogs, foxes and pigs). Isospora belli has an anthroponotic life cycle and is transmitted through food or water contaminated with human feces; it is, therefore, not a zoonosis ${ }^{1}$.

Infection of immunocompetent individuals by the coccidia results in self-limiting acute diarrhea, and has a reported prevalence ranging between 14 and $13.1 \%$ in patients with diarrhea ${ }^{2}$. Infection of immunocompromised individuals causes severe prolonged or chronic diarrhea with simultaneous elimination of infectious microbes that represent a public health problem ${ }^{3}$. The prevalence of isosporiasis in patients suffering from human immunodeficiency virus/acquired immunodeficiency syndrome (HIV/AIDS) is variable, reflecting the frequency of the parasite in different countries; it is considered an AIDS-defining illnesses ${ }^{4}$.

Common variable immunodeficiency (CVID) is the most frequent symptomatic primary immunodeficiency, characterized by recurrent bacterial infections, hypogammaglobulinemia, and impaired antibody responses. Common variable immunodeficiency patients usually present with recurrent respiratory infections and an increased incidence of autoimmune, gastrointestinal, lymphoproliferative, and granulomatous diseases ${ }^{4}$. Although CIVD is classified as an antibody deficiency, a significant number of studies have identified alterations in the phenotype and function of T cell subpopulations ${ }^{5}$.

\section{CASE REPORT}

The patient was a 62-year-old Caucasian female presenting with a 12 month history of diarrhea. She reported watery diarrhea with mucus, but without blood or purulent secretions, which was

Address to: Dr. Gesmar Rodrigues Silva Segundo. Ambulatório de Alergia e Imunologia/ HC/UFU. Av. Pará 1720, Campus Umuarama, 38400-920 Uberlândia, MG, Brasil.

Phone/Fax: 5534 3236-6299; Mobile: 5534 9979-0809

e-mail: gesmar@famed.ufu.br

Received in 19/12/2011

Accepted in 30/03/2012 associated with loss of appetite, abdominal pain, and intermittent fever. The patient lost approximately $20 \mathrm{~kg}$ in body weight during this period. She also reported a history of recurrent infections, including several episodes of acute rhinosinusitis over 7 years, which resulted in a sinusotomy at 59 years-of-age. At age 48, she presented with a pneumopathy and was treated for tuberculosis for 6 months. At age 50 , she also presented with an acute pneumonia treated with antibiotics at home.

The patient was admitted to hospital for treatment and further investigations. During hospitalization, we confirmed that she was suffering from malabsorptive diarrhea and steatorrhea. Examination of her stools was performed, along with a colonoscopy and an endoscopy of the esophagus, stomach and duodenum. Anatomopathological analysis of a duodenal biopsy revealed the presence of Giardia lamblia and parasitological examination of the stool samples identified Isospora belli oocysts. The isosporiasis was treated with trimethoprimsulfamethoxazole $(800 \mathrm{mg}$ i.v. for 10 days, followed by $400 \mathrm{mg}$ orally for 20 days), and the giardiasis was treated with metronidazole for 14 days, resulting in a rapid improvement of the diarrhea.

An immunodeficiency was suspected because of the Isospora infection; however, HIV tests were negative. Therefore, further evaluation of the immune system was performed, including measurement of immunoglobulin dosage and lymphocyte subset analysis. The results revealed a marked reduction in B lymphocyte numbers and immunoglobulins (Table 1). A negative values of IgG against rubella and hepatitis $B$ was found after vaccines.

TABLE 1 - Laboratorial tests to patient's immunologic screen.

\begin{tabular}{lcc}
\hline Laboratorial tests & Results & Normal values \\
\hline Anti-HIV & negative & negative \\
IgA (mg/dl) & 12.2 & $70-374$ \\
$\operatorname{lgG}(\mathrm{mg} / \mathrm{dl})$ & 12.7 & $680-1,445$ \\
$\operatorname{lgM}(\mathrm{mg} / \mathrm{dl})$ & 0.5 & $34-214$ \\
\hline T cell subsets & & \\
CD19 cel $/ \mathrm{mm}^{3}(\%)$ & $64(4.5)$ & $138-544$ \\
CD3 cel $/ \mathrm{mm}^{3}(\%)$ & $1,049(73.8)$ & $1,000-3,900$ \\
CD4 cel $/ \mathrm{mm}^{3}(\%)$ & $508(35.7)$ & $476-1,136$ \\
CD8 cel $/ \mathrm{mm}^{3}(\%)$ & $539(37.9)$ & $248-724$ \\
\hline
\end{tabular}

IgA: immunoglobulin A, IgG: immunoglobulin G, IgM: immunoglobulin M. 
Normal levels of albumin associated with low levels of immunoglobulin are characteristic of hypogammaglobulinemia. A diagnosis of CVID was suggested and treatment with intravenous immunoglobulin (IVIg) was initiated. After 5 months of IVIg treatment (one treatment per month), the patient regained normal bowel function and gained $17 \mathrm{~kg}$ in weight.

\section{DISCUSSION}

Common variable immunodeficiency (CVID) is characterized by a primary deficiency in antibodies and diagnosis is confirmed by a reduction in serum immunoglobulin $G(\operatorname{Ig} G)$, immunoglobulin $A$ ( $\lg A)$ and/or immunoglobulin M (IgM) levels (less than two standard deviations of the reference level for age) and poor responses to vaccination with polysaccharide (Streptococcus pneumoniae and Haemophilus influenzae) and protein (tetanus and diphtheria) antigens ${ }^{6}$. Other causes of hypogammaglobulinemia must be excluded, including drugs that induce immunodeficiency, gastrointestinal or renal loss of immunoglobulins, and other primary antibody deficiencies ${ }^{5,6}$.

The basic defect in CIVD is the inability of B lymphocytes to differentiate into plasma cells capable of producing the various immunoglobulin isotypes. Defective B cell development results in abnormal humoral immune responses that result in hypogammaglobulinemia, which manifests clinically as an increased susceptibility to infection 7 . Patients with CVID often develop acute sinopulmonary infections that can lead to chronic inflammation of the airways, such as chronic sinusitis and bronchiectasias ${ }^{4,5}$.

Over the last 20 years, various facets of the cellular and immunological dysfunctions present in CVID have been described; for example, abnormalities in B cell populations, a low frequency of naive CD4 T cells, and an increase in cellular activation. Other immunological defects include a reduction in the absolute number of natural killer cells and defects in dendritic cell function ${ }^{8}$. Around $30 \%$ of CVID patients develop autoimmune diseases associated with abnormalities in Treg cells, particularly hemolytic anemia and idiopathic thrombocytopenic purpura, autoimmune thyroiditis, inflammatory intestinal diseases, pernicious anemia, Sjögren's syndrome, autoimmune hepatitis, primary biliary cirrhosis, and vasculitis 4 .

Chronic diarrhea in adults is considered a warning sign for immunodeficiency as described by the Primary Immune Foundation and the Jeffrey Modell Foundation ${ }^{9}$, and screening for Primary Immunodeficiency should be performed in patients with one of the signs listed in Table 2. Patients with CIVD usually present with chronic diarrhea, sometimes as a consequence of an intestinal inflammatory disease; however, the presence of infectious agents should still be investigated in these patients. Several papers describe chronic diarrhea in CVID patients associated with different pathogens such as Giardia,

\section{TABLE 2 - Ten warning signs for primary immunodeficiency in adults.}

1. Two or more new ear infections within 1 year.

2. Two or more new sinus infections within 1 year, in the absence of allergy.

3. One pneumonia per year for more than 1 year.

4. Chronic diarrhea with weight loss.

5. Recurrent viral infections (colds, herpes, warts, condyloma).

6. Recurrent need for intravenous antibiotics to clear infections.

7. Recurrent, deep abscesses of the skin or internal organs.

8. Persistent thrush or fungal infection on skin or elsewhere.

9. Infection with normally harmless tuberculosis-like bacteria.

10. A family history of primary immunodeficiency
Cryptosporidium, Cytomegalovirus and Strongyloides ${ }^{5,10-12}$; however, there are no reports of diarrhea associated with isosporiasis in CVID patients.

In conclusion, this is the first reported case of isosporiasis associated with CVID. We believe this association is common but is not often diagnosed because the investigation of isosporiasis in non-HIV patients is not standard practice and regular parasitological tests do not detect the oocysts. Common variable immunodeficiency patients with chronic diarrhea should be investigated for opportunistic and unusual pathogens as soon as they present evidence of abnormal cellular immunity. On the other hand, non-HIV patients with a diagnosis of isosporiasis must be screened for other immunological diseases, primarily CIVD.

\section{ABSTRACT IN PORTUGUESE}

\section{Imunodeficiência comum variável e isosporíase: primeiro relato de caso}

Trata-se de relato de caso de uma paciente de 62 anos, sexo feminino, HIV negativo apresentando um quadro grave de diarréia, sendo isolados Giardia lamblia e Isospora belli. Infecções incomuns e oportunistas devem ser consideradas como um sinal para alerta para que se analise o sistema imunológico. O diagnóstico de imunodeficiência de comum variável foi realizado após investigação. Este é o primeiro caso relatado de isosporíase em pacientes com imunodeficiência comum variável e mostra a importância de estar alerta tambem em relação a imunodeficiências primárias.

Palavras-chaves: Isosporiase. Imunodeficiência primária. Imunodeficiência comum variável.

\section{REFERENCES}

1. Infección por Isospora belli en pacientes con infección por VIH. Presentación de dos casos y revisión de la literatura. Rev Chil Infect 2010; 27:219-227.

2. Junod C. Isospora belli coccidiosis in immunocompetent subjects (a study of 40 cases seen in Paris). Bull Soc Pathol Exot Filiales 1988; 81:317-325.

3. Cardoso LV, Galisteu KJ, Schiesari Júnior A, Chahla LA, Canille RM, Belloto MV, et al. Enteric parasites in HIV-1/AIDS-infected patients from a Northwestern São Paulo reference unit in the highly active antiretroviral therapy era. Rev Soc Bras Med Trop 2011, 44:665-669.

4. Oliveira-Silva MB, Oliveira LR, Resende JC, Peghini BC, Ramirez LE, Lages-Silva E, et al. Seasonal profile and level of CD4+ lymphocytes in the occurrence of cryptosporidiosis and cystoisosporidiosis in HIV/AIDS patients in the Triângulo Mineiro region, Brazil. Rev Soc Bras Med Trop 2007; 40:512-515.

5. Cunningham-Rundles $C$, Bodian $C$. Common variable immunodeficiency: clinical and immunological features of 248 patients. Clin Immunol 1999; 92:34-48.

6. Cunningham-Rundles C. Common variable immunodeficiency. Curr Allergy Asthma Rep 2001; 1:421-429.

7. Conley ME, Notarangelo LD, Etzioni A. Diagnostic Criteria for Primary Immunodeficiencies. Clin Immunol 1999; 93:190-197.

8. Melo KM, Carvalho KI, Bruno FR, Ndhlovu LC, Ballan WM, et al. A Decreased Frequency of Regulatory T Cells in Patients with Common Variable Immunodeficiency. PLoS ONE 2009; 4:e6269.

9. Ten warning signs for primary immunodeficiency in adults[internet]. [Cited in Dec 2011]. Available from: www.info4pid.com/.

10. Torres J, Fortuna J, Trigo E, Lopes AM, Campos MJ, Ferreira MR. Diarreia num doente com imunodeficiência comum variável. J Port Gastrenterol 2007; 14:199-203.

11. Daniels JA, Lederman HM, Maitra A, Montgomery EA. Gastrointestinal tract pathology in patients with common variable immunodeficiency (CVID): a clinicopathologic study and review. Am J Surg Pathol 2007; 31:1800-1812.

12. Kobata $\mathrm{CH}$, Neves MC, Dutenhefner SE, Silva FS, Bianchi Junior PF, Kanshiro EH. Manifestação intestinal rara em pacientes com imunodeficiência comum variável e estrongiloidíase: relato de caso. Rev Med (São Paulo) 2000; 79:73-80. 